\title{
Braconidae (Hymenoptera) fauna in native, degraded and restoration areas of the Vale do Paraíba, São Paulo state, Brazil
}

\author{
Barbieri Junior, CA. ${ }^{a *}$ and Dias, AMP. ${ }^{b *}$ \\ aPrograma de Pós-Graduação em Ecologia e Recursos Naturais, Universidade Federal de São Carlos - UFSCar, \\ CP 676, CEP 13565-905, São Carlos, SP, Brazil \\ ${ }^{\text {b}}$ Departamento de Ecologia e Biologia Evolutiva, Universidade Federal de São Carlos - UFSCar, \\ CP 676, CEP 13565-905, São Carlos, SP, Brazil \\ *e-mail: celsomestrado@yahoo.com.br; angelica.penteado@pq.cnpq.br \\ Received May 11, 2011 - Accepted July 12, 2011 - Distributed May 31, 2012
}

(With 3 figures)

\begin{abstract}
This study sampled the diversity of Braconidae (Hymenoptera) in three different ecosystems: a degraded pasture, a secondary forest and an area in recovery process using native tree seedlings. The objective was to verify the use of those insects as a tool to check the local conservation by examining Shannon's diversity index. Ten subfamilies were identified, and Microgastrinae was predominant in a number of individuals. The diversity index calculated varies among the sampled areas, thus showing a correlation with vegetation cover with the number of individuals collected and number of subfamilies found. The results showed changes in the community of Braconidae, in the recovery area between the first and second year of study, thereby leading to the conclusion that they are indicators of environmental quality.
\end{abstract}

Keywords: Braconidae, degraded areas, diversity index, indicator species.

\section{Fauna de Braconidae (Hymenoptera) em áreas nativas, degradadas e em recuperação do Vale do Paraiba, Estado de São Paulo, Brasil}

\begin{abstract}
Resumo
Este estudo amostrou a diversidade de Braconidae (Hymenoptera) em três ecossistemas distintos: pastagem degradada, mata secundária e área em processo de recuperação com utilização de mudas de árvores nativas. O objetivo foi verificar a possibilidade de utilização desse grupo de insetos como ferramenta para identificar o estado de conservação local por meio da análise do índice de diversidade de Shannon. Foram identificadas dez subfamílias, com predominância em número de indivíduos de Microgastrinae. Os índices de diversidade calculados permitiram diferenciar as áreas amostradas, apresentando uma correlação da cobertura vegetal com o número de indivíduos coletados e o numero de subfamílias encontradas. O método evidenciou alteração na comunidade de Braconidae na área em recuperação, entre o primeiro e o segundo ano de estudo, demonstrando que são insetos indicadores de qualidade ambiental.
\end{abstract}

Palavras-chave: Braconidae, áreas degradadas, bioindicadores, índice de diversidade.

\section{Introduction}

The problem of environmental degradation is international, and there is probably no region in the world that is not affected. Daily (1995) estimated that $43 \%$ of land has had its ability to "provide benefits to mankind" reduced due to recent human impacts. In Brazil, the areas susceptible to desertification process reaches $980,711 \mathrm{~km}^{2}$ (Thomaz et al., 2009), approximately $10 \%$ of the country. One of the challenges in achieving sustainability is to reverse this situation of environmental degradation through rehabilitation of degraded land (Urbanska et al., 2000) and, in the specific case of deforested areas, the use of techniques for planting native trees (Kageyama et al., 2003).
The insects and other arthropods can be used to evaluate ecosystem recovery with great efficiency (Majer, 1990; New, 1995; Brown Junior, 2000), especially orders with a greater diversity of species such as, Lepidoptera, Coleoptera e Hymenoptera. They are very obvious, diverse and sensitive to changes in the environment (Brown Junior, 2000), allowing through population parameters, to infer indicators of ecosystem health and wealth, any change in ecological structure, decreased flow of matter and energy, and also due to their high mobility and short life cycle, the Hymenoptera are quick to announce trends of degradation, regeneration and recovery environments (Kremen, 1994; Brown Junior, 2000).

Braconidae is the second largest family of Hymenoptera, with 29 subfamilies and about 40,000 species in the world, 
approaching the global number of species of vertebrates (Achterberg, 1988; Fernandez and Sharkey, 2006). The evaluation of the diversity of this group in order to study taxonomy, conservation, environmental monitoring or evaluation of areas of recovery, are also highly relevant.

According to several authors (Whitfield and Lewis, 1999; Gonzáles and Ruíz, 2000), the parasitoids of the family group can be used as an indicator of the degree of preservation, as bioindicators of the effects of anthropogenic activities on ecosystems and to estimate the richness of species found in a given region.

The aim of this study was to assess the efficiency of utilization of the diversity of subfamilies of Braconidae as indicators of environmental quality of an area in the process of environmental recovery in the northeast of São Paulo state, Brazil.

\section{Material and Methods}

This study was conducted on a farm called Sítio Ymyrá (23 $3^{\circ} 15^{\prime} 17.55^{\prime}$ ' S and 46 01' 21.74" W and $598 \mathrm{~m}$ of altitude), Jacareí city, a region of the Médio Vale do Paraiba, São Paulo state, Brazil. The study area was divided into three subareas of approximately $10,000 \mathrm{~m}^{2}$ each, resulting in a area of forest in an advanced stage of natural regeneration and two areas with degraded pasture, with absolute predominance of Brachiaria decumbens Stapf. One of the areas occupied by degraded pasture held the work of ecological restoration of planting native trees in the period of 10 to 20 September 2007. The choice of tree species to be planted was based on a floristic survey carried out previously in the adjacent area of secondary forest, and planting of seedlings followed the model proposed by Kageyama et al. (2003).

Table 1. Data of occurrence of the Braconidae subfamilies collected at SítioYmyrá, Jacareí town, São Paulo state, Brazil, from September 2007 to August 2009 using Malaise traps.

\begin{tabular}{lcccc}
\hline \multicolumn{1}{c}{ Subfamilies } & Degraded pasture & Restoration area & Secondary forest & Total \\
\hline Alysiinae & 0 & 9 & 34 & 43 \\
Braconinae & 9 & 7 & 28 & 44 \\
Cheloninae & 4 & 7 & 62 & 73 \\
Euphorinae & 1 & 2 & 7 & 10 \\
Gnamptodontinae & 0 & 8 & 43 & 51 \\
Helconinae & 0 & 1 & 5 & 6 \\
Meteorinae & 5 & 6 & 56 & 67 \\
Microgastrinae & 99 & 143 & 421 & 663 \\
Opiinae & 3 & 0 & 9 & 22 \\
Rogadinae & 0 & 103 & 7 & 7 \\
Total & 121 & 672 & 986 \\
\hline
\end{tabular}

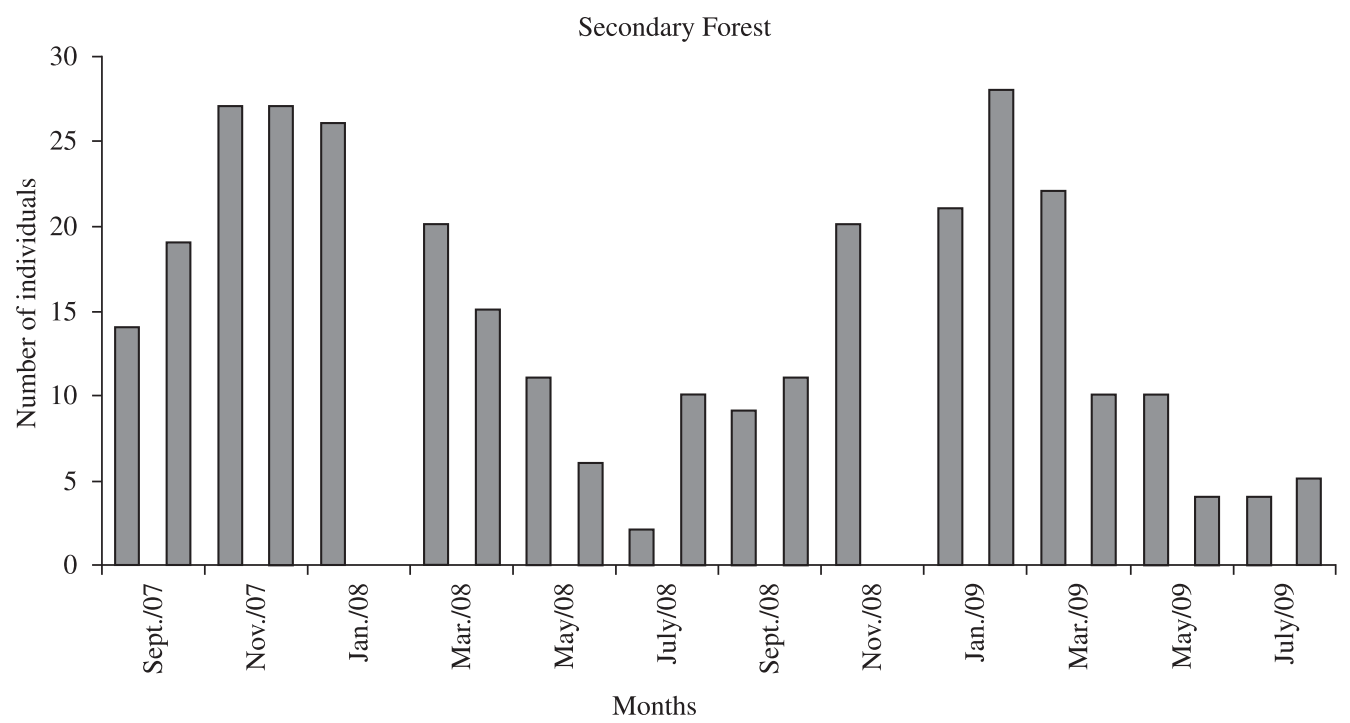

Figure 1. Number of individuals (Braconidae) as a function of months of study, collected in the area of secondary forest at Sítio Ymyrá, Jacareí city, Brazil, from September 2007 to August 2009 using Malaise traps. 
Three Malaise traps were placed within their respective areas, $250 \mathrm{~m}$ equidistant from each other, being called, respectively, secondary forest, degraded pasture and restoration area.

The period of study was from September 2007 to August 2009, resulting in 24 samples for each study area. Three of these samples were discarded for damage caused by animals and by fire. In the months when a trap was damaged, all data collected were not used for statistical analysis. Voucher specimens of parasitoid were deposited in the collection of the Federal University of São Carlos, (DCBU curator A.M.Penteado-Dias).
The material was sorted and the identification of the subfamilies of Braconidae followed Wharton et al. (1997) was used on the data obtained for each study area was used, compared by $t$-test (Hutcheson, 1970). We considered a range of $95 \%$ confidence $(\alpha=0.05)$.

\section{Results}

We captured 986 specimens of Braconidae (Table 1). The secondary forest had the highest number of individuals with 672 , followed by the restoration area with 193 individuals and the degraded pasture with

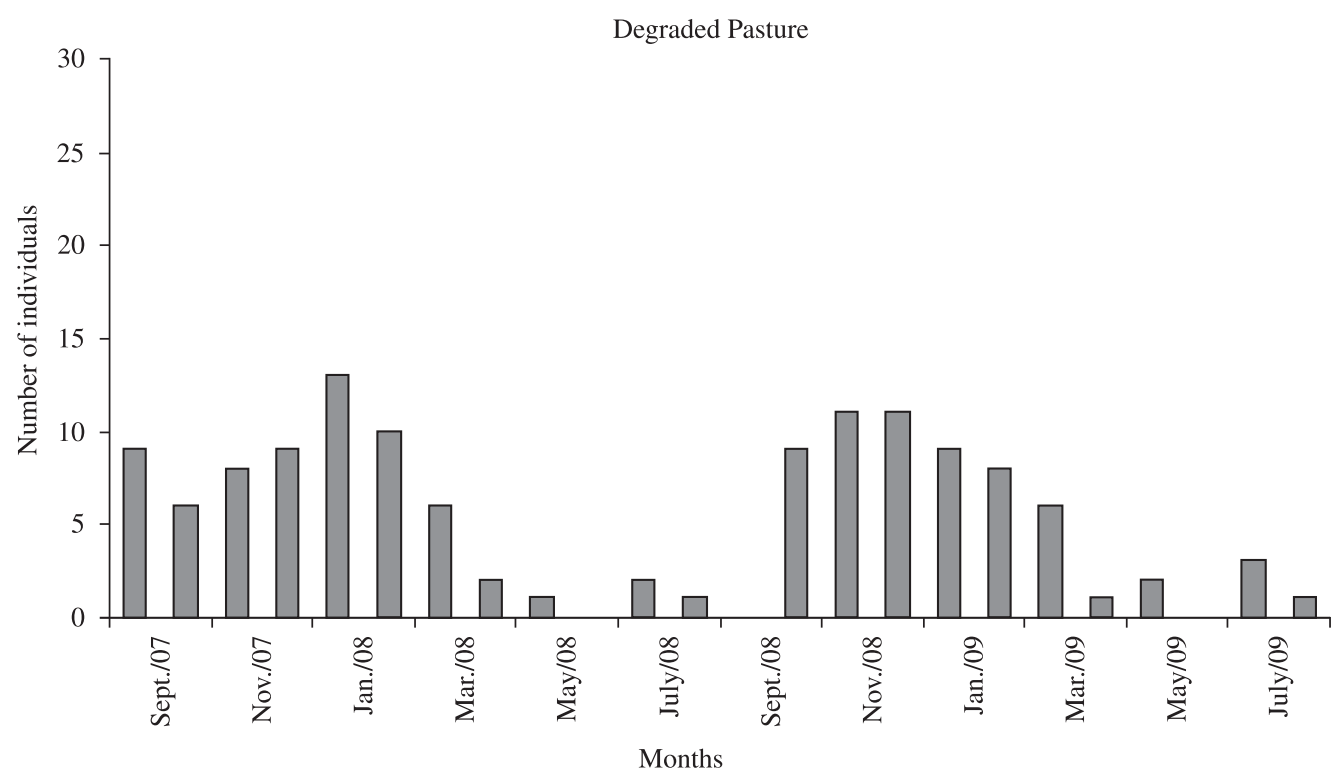

Figure 2. Number of individuals (Braconidae) as a function of months of study, collected in the area of degraded pasture, at Sítio Ymyrá, Jacareí city, Brazil, from September 2007 to August 2009 using Malaise traps.

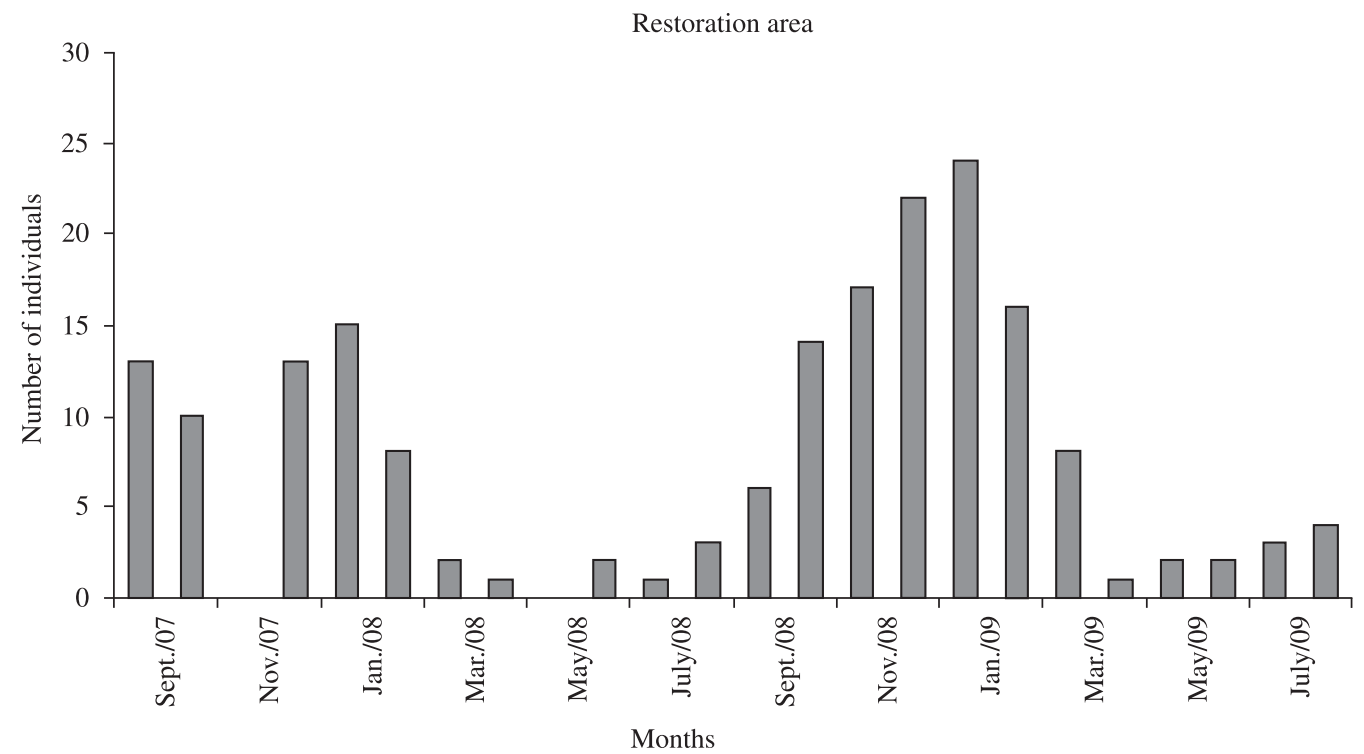

Figure 3. Number of individuals (Braconidae) as a function of months of study, collected in the restoration area at Sítio Ymyrá, Jacareí city, Brazil, from September 2007 to August 2009 using Malaise traps. 
Table 2. Analysis of Shanon index values of diversity and uniformity obtained for Braconidae collected at the Sítio Ymyrá, Jacareí town, São Paulo state, Brazil, from September 2007 to August 2009 using Malaise traps.

\begin{tabular}{lcccc}
\hline \multicolumn{1}{c}{ Local } & N & H' & SH' & J' \\
\hline Degraded pasture (first year) & 64 & 0.25336 & 0.00257 & 0.43 \\
Degraded pasture (second year) & 57 & 0.32218 & 0.00427 & 0.41 \\
Restoration area (first year) & 74 & 0.36008 & 0.00331 & 0.46 \\
Restoration area (second year) & 119 & 0.48868 & 0.00262 & 0.52 \\
Secondary Forest (first year) & 374 & 0.65761 & 0.00019 & 0.67 \\
Secondary Forest (second year) & 298 & 0.62289 & 0.00022 & 0.63 \\
Total & 986 & & & \\
\hline
\end{tabular}

Table 3. Comparison of the Diversity Index of Braconidae subfamilies collected at the Sítio Ymyrá, Jacareí city, São Paulo State, Brazil, from September 2007 to August 2009 using Malaise traps. Where: $p d=$ degraded pasture, ar = restoration area and $\mathrm{ms}=$ secondary forest.

\begin{tabular}{lcccccccc}
\hline & \multicolumn{3}{c}{ Year 1 } & \multicolumn{3}{c}{ Year 2 } \\
\hline Combinations & Calculated t & t critical & d.f. & Result & Calculated t & t critical & d.f. & Result \\
\hline H'pd $\times$ H'ms & 7.679 & 1.664 & 80 & Differ & 4.484 & 1.668 & 69 & Differ \\
H'pd $\times$ H'ar & 1.391 & 1.656 & 141 & Do not differ & 2.004 & 1.656 & 135 & Differ \\
H'ms $\times$ H'ar & 5.022 & 1.664 & 83 & Differ & 2.511 & 1.656 & 140 & Differ \\
\hline
\end{tabular}

Table 4. Comparison of Diversity Index subfamilies of Braconidae collected at the Sítio Ymyrá, Jacareí town, Brazil, from September 2007 to August 2008 (first year) and September 2008, August 2009 (second year), using Malaise traps. Where $H^{\prime}=$ Shannon diversity index, $\mathrm{pd} 1=$ degraded pasture in the first year, $\mathrm{pd} 2=$ degraded pasture in the second year, $\operatorname{ar} 1=$ restoration area in the first year, ar2 = restoration area in the second year, ms $1=$ secondary forest in the first year and $\mathrm{ms} 2=$ secondary forest in the second year.

\begin{tabular}{ccccc}
\hline Combinations & Calculated t & t critical & d.f. & Result \\
\hline H'pd1 $\times$ H'pd2 & 0.83 & 1.965 & 487 & Do not differ \\
H'ms1 $\times$ H'ms2 & 1.634 & 1.646 & 959 & Do not differ \\
H'ar1 $\times$ H'ar2 & 2.011 & 1.974 & 171 & Differ \\
\hline
\end{tabular}

121. The three areas presented in the months of highest average rainfall, the greater number of individuals captured and greater diversity index subfamilies. The months of winter and low rainfall presented lowest number of individuals and diversity index for all three areas (Figures 1, 2 and 3).

This study observed the occurrence of ten (Table 1) of the 34 subfamilies quoted by Wharton et al. (1997) as occurring to the New World: Alysiinae, Braconinae, Cheloninae, Euphorinae, Gnamptodontinae, Helconinae, Meteorinae, Microgastrinae, Opiinae and Rogadinae.

All subfamilies mentioned above were observed in the secondary forest; Rogadinae was exclusive in the secondary forest. In the degraded pasture area, Braconinae, Cheloninae, Euphorinae, Meteorinae, Microgastrinae and Opiinae occurred.

Independently of sampling area, Microgastrinae was predominant (Table 1). Only the restoration area showed a significant difference in diversity index during the first and second years, when compared individually to the other two areas, as shown in Tables 2, 3 and 4.

\section{Discussion}

The results corroborate those obtained by Scatolini and Penteado-Dias (2003) with a greater frequency of these insects in the months of November and December caught by a light trap at locations in Paraná state, Brazil. In turn, the observed data differ from those reported by Cirelli and Penteado-Dias (2003), examining the phenology of the Braconidae caught in Malaise traps in a cerrado (= Brazilian savanna) area of Descalvado, São Paulo state, Brazil, recording the highest frequencies of occurrence in June and August (winter) and September (early spring).

Those differences may be explained partly by the fact that the studies were conducted in regions with different climatic conditions, which influence the abundance and availability of hosts during the sampling period.

The widespread occurrence of Microgastrinae in all samples can be explained by the fact that this subfamily is considered as the most common group of parasitoids of Lepidoptera in the world (Wharton et al., 1997).

Analysing the data obtained, it was possible to verify that even small forest fragments, although impacted, may 
harbour significant differences in diversity and uniformity when compared with nearby areas, completely deforested (Table 2).

In addition to providing a wider range of potential host plants, the forest, even if impacted, provides a microclimate quite different from that observed in completely deforested areas (Rodrigues and Leitão Filho, 2000), thereby confirming the importance of conservation of forest fragments, even small ones and those already impacted by human activity.

The difference in diversity index, observed in the second year of sampling in the restoration area compared with the degraded pasture (Table 3 ), can be explained by the fact that the seedlings planted grew fast in the second year, producing many shoots and young leaves ideal for the proliferation of possible Braconidae hosts.

Currently, the official criteria evaluating the success of a forest restoration project in Brazil is based solely on the planting of native tree species in a given population density prescribed, which aims to recollect the local natural habitat (São Paulo, 2008). In most terrestrial ecosystems, plants are not always good indicators of environmental quality, the progress of colonisation by other species, self-regulation and local environmental stability, because they may not respond to environmental changes, or the apparent speed required for certain impacts can be perceived and corrective measures can be taken (Noss, 1990; Williams, 2003).

Results revealed that Braconidae, even at the level of subfamily, can be used for environmental monitoring and that only the planting of native tree species in the study area can change representatively its diversity. This study confirms the data obtained by Azevedo and Santos (2000) and Azevedo et al. (2002), regarding the use of parasitoid wasps in the study of animal communities, distinguishing areas with different degrees of impact.

Acknowledgements - To all the people involved in the Laboratory of Parasitic Hymenoptera of the Departamento de Ecologia e Biologia Evolutiva of the Federal University of São Carlos, who helped us in this work, especially Clóvis Sormus de Castro Pinto, Eduardo Mitio Shimbori and Helena Carolina Onody. Special thanks to Eloir Gonçalves dos Santos, for helping us in the preparation area, planting seedlings and mainly in defense against the fire of the driest months, as well to all employees of the Viveiro Ymyrá. To the Conselho Nacional Científico e Tecnológico (CNPq), Fundação de Amparo a Pesquisa do Estado de São Paulo (FAPESP), Coordenação de Aperfeiçoamento de Pessoal de Nível Superior (CAPES) and INCT dos Hymenoptera Parasitoides da Região Sudeste Brasileira for financial support.

\section{References}

ACHTERBERG, CV., 1988. Revision of the subfamily Blacinae Foerster (Hymenoptera: Braconidae). Zoologische Verhandelingen, vol. 249 , p. 1-324.

AZEVEDO, CO., KAWADA, R., TAVARES, MT. and PERIOTO, NW., 2002. Perfil da fauna de himenópteros parasitóides (Insecta, Hymenoptera) em uma área de Mata Atlântica do Parque Estadual da Fonte Grande, Vitória, ES, Brasil. Revista Brasileira de Entomologia, vol. 46, no. 2, p. 133-137.
AZEVEDO, CO. and SANTOS, HS., 2000. Perfil da fauna de himenópteros parasitóides (Insecta, Hymenoptera) em uma área de Mata Atlântica da Reserva Biológica de Duas Bocas, Cariacica, ES, Brasil. Boletim do Museu de Biologia Mello Leitão, vol. 11, p. $117-126$.

BROWN JUNIOR, KS., 2000. Insetos indicadores da história, composição, diversidade, e integridade de matas ciliares tropicais. In RODRIGUES, RR. and LEITÃO FILHO, HF. (Eds.). Matas ciliares: conservação e recuperação. São Paulo: EdUSP; FAPESP. p. $250-262$.

CIRELLI, KRN. and PENTEADO-DIAS, AM., 2003. Fenologia dos Braconidae (Hymenoptera, Ichneumonoidea) da Área de Proteção Ambiental (APA) de Descalvado/SP. Revista Brasileira de Entomologia, vol. 47, no. 1, p. 99-105. http://dx.doi.org/10.1590/ S0085-56262003000100015

DAILY, CG., 1995. Restoring value to the world's degraded lands. Science, vol. 269, p. 350-354. PMid:17841252. http://dx.doi. org/10.1126/science.269.5222.350

FERNÁNDEZ, F. and SHARKEY, MJ. (Eds.), 2006. Introducción a los Hymenoptera de la Región Neotropical. Bogotá: Sociedad Colombiana de Entomologia y Universidad Nacional de Colômbia. 894 p.

GONZÁLES, HD. and RUÍZ, DB., 2000. Los Braconidos (Hymenoptera: Braconidae) como grupo parametro de biodiversidade em las selvas decíduas del tropico: uba discusion acerca de su posible uso. Acta Zoológica Mexicana, vol. 79, p. 43-56.

HUTCHESON, K., 1970. A test for comparing diversities based on Shannon formula. Journal of Theoretical Biology, vol. 29, p. 151-154. http://dx.doi.org/10.1016/0022-5193(70)90124-4

KAGEYAMA, PY., OLIVEIRA, RE., MORAES, LFD. ENGEL, VL. and GASTANDARA, FB. (Orgs.), 2003. Restauração ecológica de ecossistemas naturais. Botucatu: FEPAF. 340 p.

KREMEN, C.,1994. Biological inventory using target taxa: a case study of the butterflies of Madagascar. Ecological Applications, vol. 4, p. 407-22. http://dx.doi.org/10.2307/1941946

MAJER, JD., 1990. Rehabilitation of disturbed land: long-term prospects for the recolonization of fauna. Proceedings of the Ecological Society of Australia, vol. 16, p. 509-519.

NEW, TR., 1995. Introduction to invertebrate conservation biology. Oxford: Oxford University Press. 206 p.

NOSS, RF., 1990. Indicators for monitoring biodiversity: a hierarchical approach. Conservation Biology, vol. 4, p. 355-364. http://dx.doi.org/10.1111/j.1523-1739.1990.tb00309.x

RODRIGUES, RR. and LEITÃO FILHO, HF., 2000. Matas ciliares: conservação e recuperação. São Paulo: EdUSP; FAPESP. 320 p.

São Paulo (Estado). Secretaria do Meio Ambiente - SMA, 2008. Resolução SMA 08, de 31 de janeiro de 2008. Fixa a orientação para o reflorestamento heterogêneo de áreas degradadas e dá providências correlatas. Diário Oficial do Estado de São Paulo, Poder Executivo, São Paulo, SP, 01 fev. 2008. Seção I, p. 31-32.

SCATOLINI, D. and PENTEADO-DIAS, AM., 2003. Análise faunística de Braconidae (Hymenoptera) em três áreas de mata nativa do Estado do Paraná, Brasil. Revista Brasileira de Entomologia, vol. 47, no. 2, p. 187-195. http://dx.doi.org/10.1590/ S0085-56262003000200006

THOMAZ, C., OLIVEIRA, MAJ., ACCIOLY, 1JO. and SILVA, FHBB., 2009. Análise da degradação da caatinga no núcleo de 
desertificação do Seridó (RN/PB). Revista Brasileira de Engenharia Agrícola e Ambiental, vol. 13, p. 961-974.

URBANSKA, KM., WEBB, NR. and EDWARDS, PJ., 2000.

Restoration ecology and sustainable development. Cambridge: Cambridge University Press. 397 p.

WHARTON, RA., MARSH, PM. and SHARKEY, MJ. (Eds.), 1997. Manual of the New World Genera of the Family Braconidae (Hymenoptera). Washington: Special Publication of The International Society of Hymenopterists. vol. 1, 439 p.
WHITFIELD, JB. and LEWIS, CN., 1999. Analytical survey of braconid wasps fauna (Hymenoptera: Braconidae) on six Midwestern U.S. tallgrass prairies. Annals of the Entomological Society of America, vol. 94, no. 2, p. 231-238.

WILLIAMS, SE., 2003. Impacts of global climate change on the rainforest vertebrates of the Australian Wet Tropics. In HOWDEN, M., HUGHES, L., DUNLOP, M., ZETHOVEN, I., HILBERT, D. and CHILCOTT, C. (Eds.). Climate change impacts on Biodiversity in Australia. Canberra: Commonwealth of Australia. p. 50-52. 